Article

\title{
In Vitro Anticancer Drug Sensitivity Sensing through Single-Cell Raman Spectroscopy
}

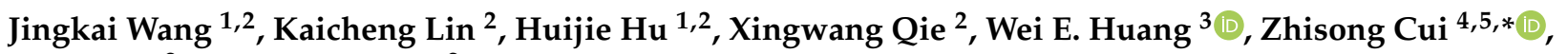 \\ Yan Gong ${ }^{2, *}$ and Yizhi Song ${ }^{2, *}$
}

1 Division of Life Sciences and Medicine, School of Biomedical Engineering (Suzhou), University of Science and Technology of China, Hefei 230026, China; wangjk@sibet.ac.cn (J.W.); huhj@sibet.ac.cn (H.H.)

2 Suzhou Institute of Biomedical Engineering and Technology, Chinese Academy of Sciences, Suzhou 215163, China; linkc@sibet.ac.cn (K.L.); qiexw@sibet.ac.cn (X.Q.)

3 Department of Engineering Science, University of Oxford, Parks Road, Oxford OX1 3PJ, UK; wei.huang@eng.ox.ac.uk

4 Marine Bioresources and Environment Research Center, First Institute of Oceanography, Ministry of Natural Resources of China, Qingdao 266061, China

5 Laboratory for Marine Ecology and Environmental Science, Qingdao National Laboratory for Marine Science and Technology, Qingdao 266071, China

* Correspondence: czs@fio.org.cn (Z.C.); gongy@sibet.ac.cn (Y.G.); songyz@sibet.ac.cn (Y.S.)

\section{check for}

updates

Citation: Wang, J.; Lin, K.; Hu, H.; Qie, X.; Huang, W.E.; Cui, Z.; Gong, Y.; Song, Y. In Vitro Anticancer Drug Sensitivity Sensing through SingleCell Raman Spectroscopy. Biosensors 2021, 11, 286. https://doi.org/ 10.3390/bios11080286

Received: 16 July 2021

Accepted: 17 August 2021

Published: 20 August 2021

Publisher's Note: MDPI stays neutral with regard to jurisdictional claims in published maps and institutional affiliations.

Copyright: (c) 2021 by the authors. Licensee MDPI, Basel, Switzerland. This article is an open access article distributed under the terms and conditions of the Creative Commons Attribution (CC BY) license (https:/ / creativecommons.org/licenses/by/ $4.0 /)$.

\begin{abstract}
Traditional in vitro anticancer drug sensitivity testing at the population level suffers from lengthy procedures and high false positive rates. To overcome these defects, we built a confocal Raman microscopy sensing system and proposed a single-cell approach via Raman-deuterium isotope probing (Raman-DIP) as a rapid and reliable in vitro drug efficacy evaluation method. Raman-DIP detected the incorporation of deuterium into the cell, which correlated with the metabolic activity of the cell. The human non-small cell lung cancer cell line HCC827 and human breast cancer cell line MCF-7 were tested against eight different anticancer drugs. The metabolic activity of cancer cells could be detected as early as $12 \mathrm{~h}$, independent of cell growth. Incubation of cells in $30 \%$ heavy water $\left(\mathrm{D}_{2} \mathrm{O}\right)$ did not show any negative effect on cell viability. Compared with traditional methods, Raman-DIP could accurately determine the drug effect, meanwhile, it could reduce the testing period from $72-144 \mathrm{~h}$ to $48 \mathrm{~h}$. Moreover, the heterogeneity of cells responding to anticancer drugs was observed at the single-cell level. This proof-of-concept study demonstrated the potential of Raman-DIP to be a reliable tool for cancer drug discovery and drug susceptibility testing.
\end{abstract}

Keywords: chemotherapy; drug efficacy; cancer cell; Raman spectroscopy; single cell

\section{Introduction}

The discovery, screening, and administration of safe and effective anticancer drugs are vital for tackling cancers. In vitro drug testing is a key step in evaluating the efficacy of anticancer drugs. It is extensively carried out not only during drug development to screen candidates entering clinical trials but also before medical treatment to find the right medication for individual patients when many drugs become ineffective due to drug resistance. Considering the long duration and high cost of drug development, as well as the consequences of inappropriate medication, it is important to develop reliable and effective platforms for screening anticancer molecules [1,2].

In vitro drug screening is traditionally performed on cell lines by examining their viability or proliferation after exposure to drugs. These methods detect the cell viability at the population level by measuring cellular oxidoreductase (e.g., NADP $(\mathrm{H})$ and dehydrogenase) activity or adenosine triphosphate (ATP) synthesized only in viable cells. Common methods of in vitro screening include a colorimetric tetrazolium reduction (MTT) assay or other commercially available derivatives such as cell counting kit-8 (CCK-8) or CellTiter-Glo kit (CTG) [3]. 
However, traditional in vitro drug sensitivity testing methods have several limitations that contribute to the high drug attrition rates in oncology and incorrect susceptibility results for precision medication [4]: (1) Cell viability tests often have false results. For example, reagent-associated toxicity issues contribute to false positives [5]. In addition, the redox potential, oxidative stress, and other oxidoreductases that react with the colorimetric substrate also affect the results [6]. (2) Traditional assays normally require a long duration (72-144 h), during which time alterations in the media, drugs, and cells can impact the results [7]. Long procedural delays can prevent patients from receiving appropriate treatment. (3) The heterogeneity of tumor cells plays an important role in cancer development, as well as cancer drug resistance. Unfortunately, population-based experiments fail to detect variations in the cell population and intra-sample heterogeneity [8]. Hence, the development of in vitro anticancer drug sensitivity detection which can involve less toxic or non-toxic compounds, shorten the procedure and reflect single-cell heterogeneity is critical to overcome these issues.

Raman scattering is commonly used in diagnosis because it is a fast, label-free, noninvasive and molecular-specific technology [9]. Surface-enhanced Raman-scattering (SERS) has been used in evaluating anticancer-drug efficacy $[10,11]$. However, universal SERS biomarkers for predicting anticancer-drug effects have not been reported. Single-cell Raman spectra (SCRS) detect the vibrational modes of biomolecules in a cell and reflect the biochemical profile or phenotype at the single-cell level. Cells/bacteria can be labeled with a stable isotope, such as ${ }^{13} \mathrm{C},{ }^{15} \mathrm{~N}$, and ${ }^{2} \mathrm{H}(\mathrm{D})$, and exhibit characteristic Raman spectra shift due to the replacement of heavy stable isotopic atoms in biomolecules [12,13]. We previously proposed a Raman-deuterium isotope probing (Raman-DIP) approach to determine the antibiotic-resistant bacteria in environmental [14] and clinical samples [15] by coupling deuterium labeling and single-cell Raman spectroscopy. The rationale behind this approach is that only metabolically active cells in the presence of antimicrobial agents and $\mathrm{D}_{2} \mathrm{O}$ could integrate deuterium and add $\mathrm{D}$ into biomolecules as carbon-deuterium (C-D) bonds. This leads to a characteristic Raman C-D band at $2000-2300 \mathrm{~cm}^{-1}$ [14]. The C-D Raman band is a universal biomarker for metabolic activity identification of various types of bacteria and archaea [14,16-20]; however, studies that address the feasibility of applying Raman-DIP to reflect the metabolic activity of cancer cells and to correlate single-cell metabolic activity with anticancer drug screening are rare.

The aim of this study was to propose and evaluate a new reliable and effective in vitro anticancer drug sensitivity approach, based on the detection of cell line metabolic activity via Raman spectroscopy at the single-cell level. The concept of this approach was demonstrated in two cancer cell lines (HCC827 and MCF-7) and eight anticancer drugs. The metabolic activity of cancer cells could be detected as early as $12 \mathrm{~h}$, independent of cell growth. We then verified its feasibility by comparing it with classical in vitro drug sensitivity tests. The new sensing approach involves no toxic chemicals and reduces the test time to $48 \mathrm{~h}$. More importantly, single-cell Raman-DIP sensing can analyze singlecell heterogeneous responses to chemotherapy drugs, which cannot be achieved with conventional approaches.

\section{Materials and Methods}

\subsection{The Setup of a Raman Microscopy Sensing System}

A schematic of the home-built Raman microscopy system is shown in Figure 1. The system contained a continuous laser (DPL $532 \mathrm{~nm} 100 \mathrm{~mW}$, Cobolt, Solna, Sweden), a home-built upright confocal Raman microscopy module adapted from Olympus upright microscope (BX43F, Olympus, Tokyo, Japan), a motorized x-y-z stage (H1P4BX, Prior, Fulbourn, Cambridge, UK), a home-built spectrometer with a CCD (charge-coupled device) (iXon Ultra 888 Ultra EMCCD, Andor, Abingdon, Oxon, UK), and a wide-field imaging camera (Kiralux CS895CU, Thorlabs, Newton, NJ, USA). Detailed system information is listed and shown in Figure S1 and Table S1. The $532 \mathrm{~nm}$ laser was used to excite the Raman scattering of single cells. The motion stage was equipped with a slide holder to 
hold sample slides and was controlled at $0.1 \mu \mathrm{m}$ accuracy. The confocal microscope was used to collect Raman scattering signal and bright-field images. The Raman scattering signal was recorded with the CCD. The system can provide a spectral resolution of $3 \mathrm{~cm}^{-1}$ and a span of $400-3400 \mathrm{~cm}^{-1}$ wavenumber range by a grating (600 lines $\left./ \mathrm{mm}\right)$.

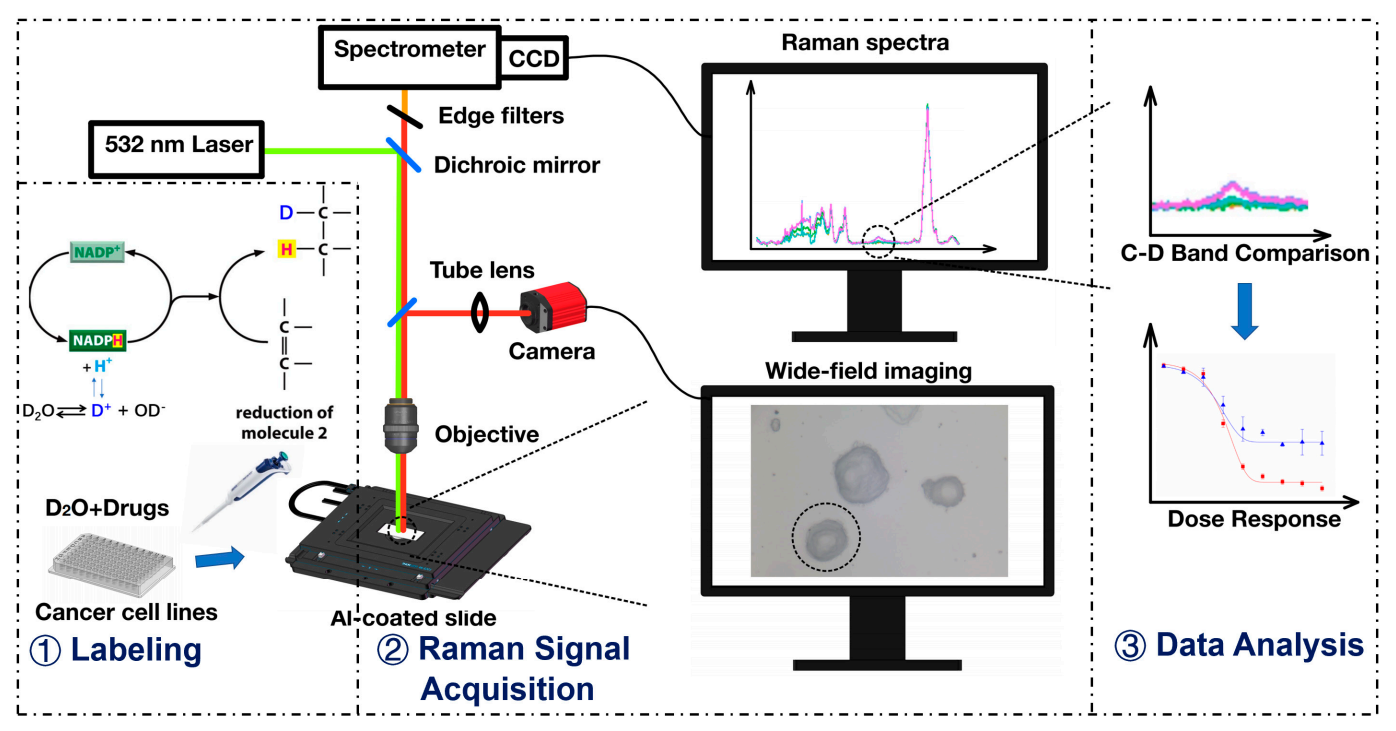

Figure 1. Schematic of the home-built Raman microscopy system and the experiment steps.

\subsection{Cell Culture}

This work used the human non-small cell lung cancer cell line HCC827 and human breast cancer cell line MCF-7 (Mlbio, Shanghai, China). The cells were cultured in a mixture of 90\% RPMI 1640 (Sigma Aldrich, Shanghai, China, 10\% FBS serum (ATTC, Manassas, VA, USA) and $1 \%$ penicillin/streptomycin (Invitrogen, Carlsbad, CA, USA). The cells were grown in an incubator at $37{ }^{\circ} \mathrm{C}$ with $5 \% \mathrm{CO}_{2}$. The cells were then sub-cultured every three days to maintain at least $50 \%$ confluence.

\subsection{Deuterium Labeling and Raman Fingerprint Acquisition}

MCF-7 and HCC827 cells (approximately $1 \times 10^{4}$ cells/well) were seeded in 96-well plates and grown overnight. The media were then removed and replaced with RPMI 1640 containing $0 \%, 5 \%, 10 \%, 20 \%, 30 \%$, and $40 \% \mathrm{D}_{2} \mathrm{O}(99.9$ atom $\%$, Sigma-Aldrich, St. Louis, MO, USA) for $24 \mathrm{~h}$, respectively. Three replicates were performed for each $\mathrm{D}_{2} \mathrm{O}$ concentration. After $24 \mathrm{~h}$, cells were removed from the wells with $0.25 \%$ trypsin (Macgene, Beijing, China) and were fixed with $4 \%$ paraformaldehyde for $10 \mathrm{~min}$ to maintain their original morphology and avoid cytolysis. To investigate the influence of labeling time, cells were incubated in RPMI 1640 containing $30 \% \mathrm{D}_{2} \mathrm{O}$ for $48 \mathrm{~h}$ in 15 replicating wells. Every $12 \mathrm{~h}$, cells were removed from 3 of the 15 wells and fixed. The fixed cells were then washed with deionized water three times to remove the medium. Next, $2 \mu \mathrm{L}$ of the cells was transferred to an aluminum-coated slide (ThermoFisher, Shanghai, China); because they provide relatively low background Raman signals, a higher signal-to-noise ratio could be guaranteed. Then, the cells were air-dried in a laminar flow chamber together with the slides. The spontaneous Raman spectra were excited with $7 \mathrm{~mW}$ laser power at the samples; an integration time of $2 \mathrm{~s}$ was used per spectrum. We randomly picked at least 10 cells in each replicate and collected 10 Raman spectra for each cell at 10 randomly selected positions.

\subsection{Toxicity of Deuterium to Cells}

MCF-7 and HCC827 cells (approximately $1 \times 10^{4}$ cells/well) were seeded in 96-well plates and grown overnight. The media were then removed and replaced with RPMI 1640 
containing $0 \%, 10 \%, 20 \%, 30 \%$, and $40 \% \mathrm{D}_{2} \mathrm{O}$ for $24 \mathrm{~h}$, with eight replicate wells for each $\mathrm{D}_{2} \mathrm{O}$ concentration. The cell viability was monitored after $24 \mathrm{~h}$ via a CCK-8 assay, following the supplier's instructions (Vitascientific, Beltsville, MD, USA). The cells cultured in the wells contained RPMI 1640 with $0 \%, 10 \%, 20 \%, 30 \%$, and $40 \% \mathrm{H}_{2} \mathrm{O}$ serving as controls.

\subsection{Anticancer Drug Treatment of Cells}

The eight anticancer drugs used in this study were non-targeted drugs (cisplatin, gemcitabine, and monomethyl auristatin E (MMAE)) and targeted drugs (osimertinib, afatinib, crizotinib, gefitinib, and icotinib); these were from Sigma-Aldrich. The $10 \mathrm{mM}$ stock solutions of the drugs were prepared by dissolving chemicals in dimethyl sulfoxide (DMSO). The working solutions were prepared by diluting the stock solution 100-fold, followed by serial 3-fold dilutions in phosphate-buffered saline (PBS). After the cells reached $50 \%$ confluence, $10 \mu \mathrm{L}$ of working solution was added to $90 \mu \mathrm{L}$ of cell cultures in 96-well plates with three replicates for each drug concentration. Two plates with cell culture reagents were treated simultaneously: one set was examined with CTG assay, and the other set used SCRS.

\subsection{Anticancer Drug Sensitivity Testing via SCRS}

After $24 \mathrm{~h}$ of exposure to anticancer drugs, $\mathrm{D}_{2} \mathrm{O}$ was added to plates at a final concentration of $30 \%$. Cells were maintained in the plates for another $24 \mathrm{~h}$ until $0.25 \%$ trypsin (Macgene, China) was added to remove cells. Then, the cells were then fixed, washed, and pipetted to acquire their SCRS following the same experimental procedures described in Section 2.3. At least 100 spectra were acquired in each replicate with an average of 10 spectra per cell. For heterogeneity analysis, an extra 150 spectra were collected from 150 HCC 827 cells treated with each concentration of crizotinib.

\subsection{Anticancer Drug Sensitivity Test by CTG Assay}

MCF-7 cells were treated with cisplatin and gemcitabine for $72 \mathrm{~h}$ and with MMAE for $144 \mathrm{~h}$. HCC827 cells were treated with gefitinib, cisplatin, afatinib, osimertinib, and icotinib for $72 \mathrm{~h}$, as well as with crizotinib for $144 \mathrm{~h}$. Cell viability was tested with the CTG assay (Promega, Beijing, China) at the end of the treatments. Briefly, CTG reagents were thawed and kept at ambient temperature for $30 \mathrm{~min}$. Reagents $(100 \mu \mathrm{L})$ were then added to each well of 96-well plates containing $100 \mu \mathrm{L}$ of cell line culture. The cells were lysed by shaking on a 96 -well plate shaker at $500 \mathrm{rpm}$ for $5 \mathrm{~min}$. The plates were then kept on the bench for $20 \mathrm{~min}$ to stabilize the luminescence. The intensity of the luminescence was recorded using a Synergy HT plate reader (Bio-Tek, Winooski, VT, USA). Wells without the addition of anticancer drugs served as negative controls.

\subsection{Data Analysis}

Unless otherwise specified, data analysis was performed using scripts developed in the programming language $\mathrm{R}$ (Version 4.0.3, R Core Team, 2020), and figures were produced using the package ggplot2 (Wickham, 2016). The Raman spectra were noise-reduced and baseline-corrected in Labspec6 (Horiba JY, Tokyo, Japan) with 10-degree linear baseline fitting algorithm. The spectra were then normalized to the intensity of the phenylalanine ring breathing peak at $1003 \mathrm{~cm}^{-1}$, for the peaks that are normally sharp and stable [21] The extent of deuterium incorporation was shown by a metabolic index, i.e., the percentage of the integrated spectral intensity of the C-D band $\left(2000-2300 \mathrm{~cm}^{-1}\right)$ compared with the sum of the C-D band and the $\mathrm{C}-\mathrm{H}$ band $\left(2800-3100 \mathrm{~cm}^{-1}\right)$. The relative cell viability was calculated as the percentage of luminescence from the CTG protocol of the drug-treated sample to that of the negative control sample. The metabolic ratio was defined as the metabolic index of drug-treated samples to the negative control. The dose-effect curve fitting was achieved in Origin 9 software (OriginLab Corporation, Northampton, MA, USA) with a sigmoidal model. Finally, the concentrations that caused a $20 \%, 30 \%, 40 \%$, and $50 \%$ inhibition in cell activity and metabolic ratio were denoted as $\mathrm{IC}_{20}, \mathrm{IC}_{30}, \mathrm{IC}_{40}$, and 
$\mathrm{IC}_{50}$, respectively (Table S3). Sensitivity, specificity, and accuracy of each criterion were calculated as described in Supplementary Document (Table S4).

\section{Results and Discussion}

\subsection{Raman Spectra of Deuterium-Labeled Cancer Single Cells}

To establish the method for deuterium labeling and SCRS acquisition of cancer cell lines, HCC827 and MCF-7 cells were incubated in media containing $\mathrm{D}_{2} \mathrm{O}$, and their SCRS were analyzed. Figure 2 shows the average SCRS of HCC 827 and MCF-7 single cells after being incubated in media containing different concentrations of $\mathrm{D}_{2} \mathrm{O}$ for various times. Compared with the treatments with $0 \% \mathrm{D}_{2} \mathrm{O}$, the SCRS of cells incubated in the $\mathrm{D}_{2} \mathrm{O}$ containing medium with a deuterium concentration as low as $5 \%$ displayed a unique Raman band near $2170 \mathrm{~cm}^{-1}$ (Figure 2A,C). In contrast, the addition of $\mathrm{D}_{2} \mathrm{O}$ did not change the intensity of Raman peaks for some important biological molecules, such as 781,1240 , and $1450 \mathrm{~cm}^{-1}$, that are assigned to nucleic acid, protein, and protein and lipids, respectively (Figure S2). In general, the intensity of the $2170 \mathrm{~cm}^{-1}$ band increased as the $\mathrm{D}_{2} \mathrm{O}$ concentration in the medium increased. Figure $2 \mathrm{~B}, \mathrm{D}$ show that the Raman band at $2170 \mathrm{~cm}^{-1}$ gradually rose with time when incubated in 30\% deuterium. Twelve hours of incubation in $\mathrm{D}_{2} \mathrm{O}$ was enough for the labeling and detection of that band.
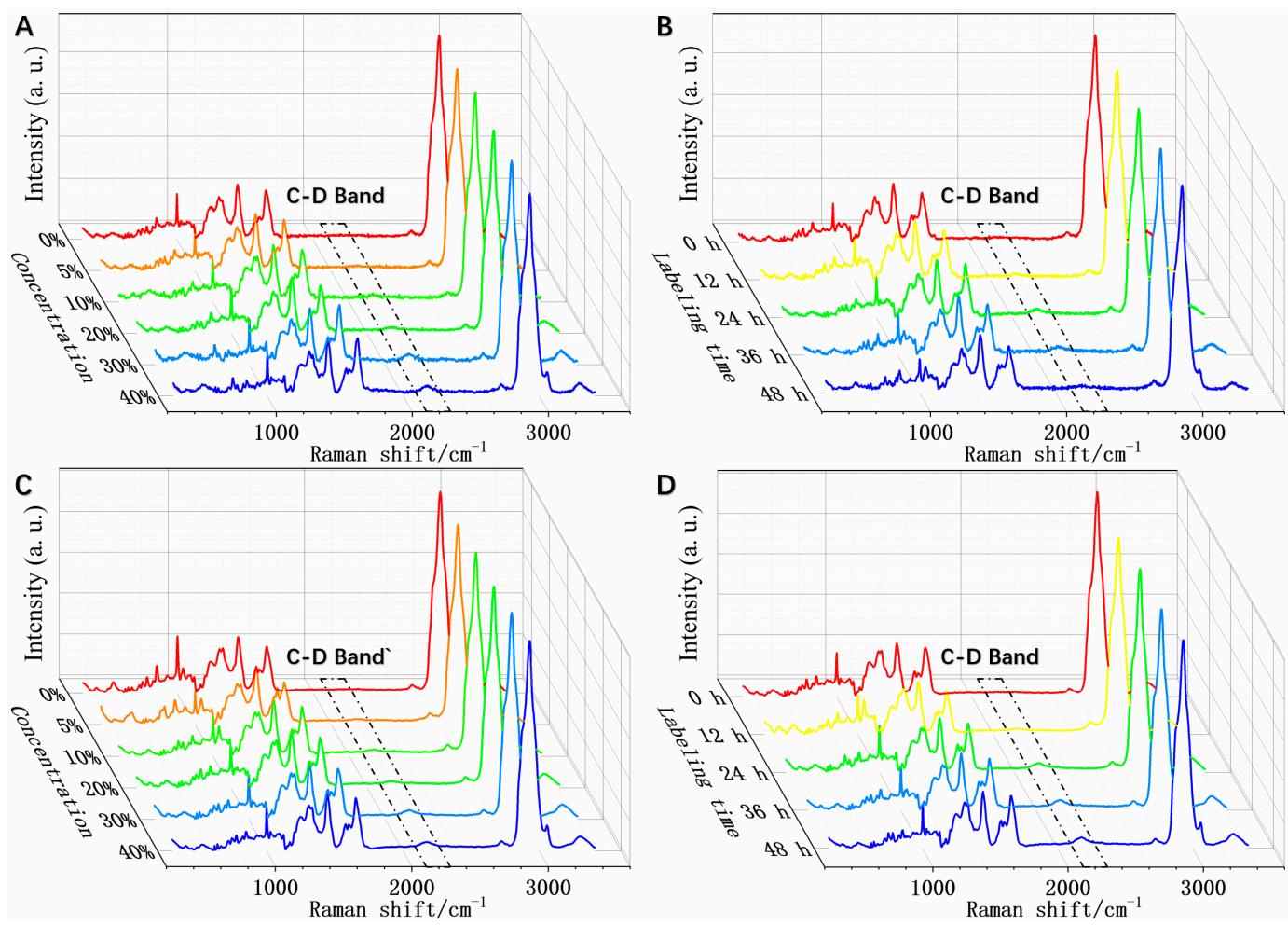

Figure 2. Single-cell Raman Spectra (SCRS) of cells after being incubated in $\mathrm{D}_{2} \mathrm{O}$-containing medium. (A) HCC827 cells incubated with various $\mathrm{D}_{2} \mathrm{O}$ concentrations for $24 \mathrm{~h}$. (B) HCC827 cells incubated in $30 \% \mathrm{D}_{2} \mathrm{O}$ for different labeling time. (C) MCF-7 cells incubated at various $\mathrm{D}_{2} \mathrm{O}$ concentrations for $24 \mathrm{~h}$. (D) MCF-7 cells incubated in $30 \% \mathrm{D}_{2} \mathrm{O}$ for different labeling time. The lines represent the average intensity $(n \geq 100)$. The spectra were baseline corrected and normalized with the intensity of the phenylalanine peak at $1003 \mathrm{~cm}^{-1}$.

The Raman spectra of biological samples reflect their fingerprints [22,23]; previous studies in which bacteria were cultured in medium containing deuterium suggested that the Raman band at $2170 \mathrm{~cm}^{-1}$ was due to the carbon-deuterium (C-D) bond in the newly synthesized lipids and protein [16]. The generation of biological building blocks containing a C-D bond was due to the incorporation of deuterium from $\mathrm{D}_{2} \mathrm{O}$ into biomolecules via NADPH regeneration by metabolically active cells; NADPH regeneration is an intracellular 
anabolic biochemical process (illustrated in Figure S3). Therefore, there was a shift in the Raman band from $2900 \mathrm{~cm}^{-1}$ (carbon-hydrogen bond) to $2170 \mathrm{~cm}^{-1}$ (C-D bond) [14,15,24]. The characteristic C-D band emerges in a range known as the 'silent zone' $\left(1800-2900 \mathrm{~cm}^{-1}\right)$ that usually does not involve vibrational modes contributed by biomolecules formed of naturally occurring isotopes. This is a distinct and easy-to-detect biomarker to evaluate the metabolic activity of a single cell [15]. Figure 2 shows that the eukaryotic cells might undergo a similar deuterium labeling process as prokaryotic cells; the $\mathrm{C}-\mathrm{D}$ band in the Raman spectra could be a universal metabolic biomarker for cancer cells.

\subsection{Influence of Deuterium Concentration and Incubating Duration on Deuterium Labeling}

To investigate the effect of $\mathrm{D}_{2} \mathrm{O}$ concentration and incubation time on deuterium labeling of cancer cells-as well as to optimize the deuterium labeling procedure-we calculated the metabolic index from the SCRS and plotted the index as shown in Figure 3. The metabolic index is an indicator of cellular metabolic activity and is defined as the ratio of the integrated spectral intensity of the C-D $\left(2040-2300 \mathrm{~cm}^{-1}\right)$ band over the sum of the C-D and C $-\mathrm{H}$ bands $\left(2800-3100 \mathrm{~cm}^{-1}\right)$.
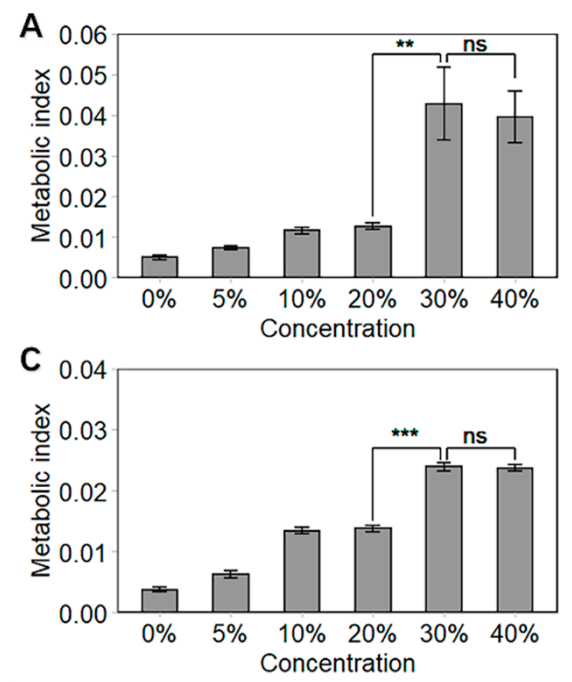
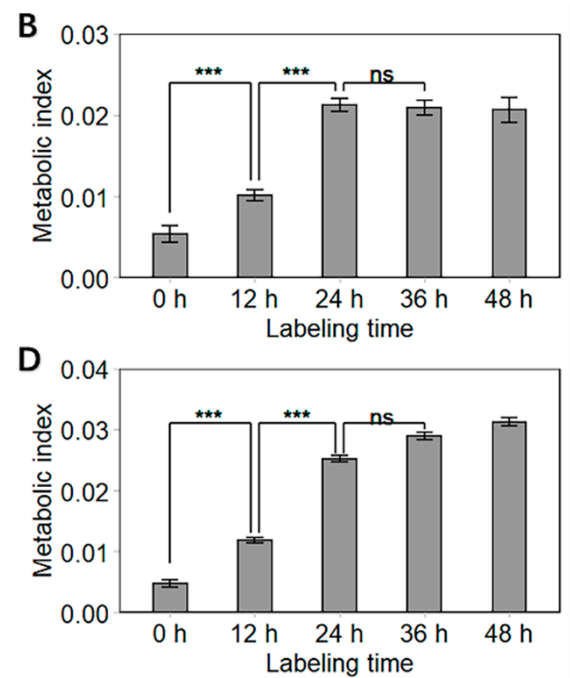

Figure 3. Single-cell metabolic index of HCC827 (A,B) and MCF-7 (C,D). Cells were incubated at various $\mathrm{D}_{2} \mathrm{O}$ concentrations for $24 \mathrm{~h}(\mathrm{~A}, \mathrm{C})$ and in $30 \% \mathrm{D}_{2} \mathrm{O}$ for different durations (B,D). Statistical significance was calculated ( $t$ test) and marked accordingly. ${ }^{* * *}: p \leq 0.001 ;{ }^{* *}: p \leq 0.01 ; \mathrm{ns}: p>0.05$, no significance. Error bars represent the standard deviation of at least 10 cells.

Figure $3 \mathrm{~A}, \mathrm{C}$ show that the metabolic index increased with increasing $\mathrm{D}_{2} \mathrm{O}$ concentration (from $5 \%-30 \%$ ). This was consistent with findings from bacterial deuterium labeling, whereby a higher deuterium composition leads to a higher proportion of deuterium in proteins and lipids [16]. Nevertheless, $40 \% \mathrm{D}_{2} \mathrm{O}$ had no benefit over $30 \%$ in terms of increasing the incorporation of deuterium into the cells ( $p$ values $>0.05$ ). Thus, $30 \% \mathrm{D}_{2} \mathrm{O}$ was chosen as the optimal concentration for deuterium labelling.

An overall ascending trend of metabolic index was demonstrated for both HCC827 and MCF-7 cells during incubation (Figure 3B,D). Here, the $12 \mathrm{~h}$ incubation in $\mathrm{D}_{2} \mathrm{O}$ was sufficient for the cells to incorporate deuterium and form $\mathrm{C}-\mathrm{D}$ bonds that could be readily detected with Raman spectroscopy. This implies that the metabolic activity detection of cancer cells was independent of cell growth for the doubling times of HCC 827 and MCF-7 were reported to exceed $24 \mathrm{~h}[25,26]$. The metabolic index differences were significant when we increased the labeling time from $12 \mathrm{~h}$ to $24 \mathrm{~h}$. In contrast, the difference in metabolic index is not significant in treatments with an incubation time between 24 and $36 \mathrm{~h}$ ( $p$ values $>0.05$ ). Thus, $24 \mathrm{~h}$ was chosen as the optimal labeling time in our protocol. 


\subsection{Effect of Deuterium on Cell Viability}

To exclude the influence of $\mathrm{D}_{2} \mathrm{O}$ on cell viability, a series of experiments were carried out by evaluating the cell viability after $\mathrm{D}_{2} \mathrm{O}$ incubation using CCK- 8 kit and by examining the cell morphologies via microscopy. Figure 4 shows that the absorbance at $450 \mathrm{~nm}$ was similar at various concentrations of $\mathrm{D}_{2} \mathrm{O}$ or $\mathrm{H}_{2} \mathrm{O}$ for $24 \mathrm{~h}$ except for $\mathrm{D}_{2} \mathrm{O}$ values over $30 \%$ ( $t$ test, $p<0.05$, Table S2). The CCK- 8 kit allows sensitive colorimetric assays for the determination of cell viability in cytotoxicity assays. This method detects the amount of yellow formazan dye reduced from a water-soluble tetrazolium salt by dehydrogenase activities in viable cells. The amount of the formazan dye is directly proportional to the number of living cells [27]. The results indicate that the differences between $\mathrm{D}_{2} \mathrm{O}$ and $\mathrm{H}_{2} \mathrm{O}$ on cell viability were not significant, especially when the $\mathrm{D}_{2} \mathrm{O}$ concentration was less than $30 \%$ (Figure 4 ).

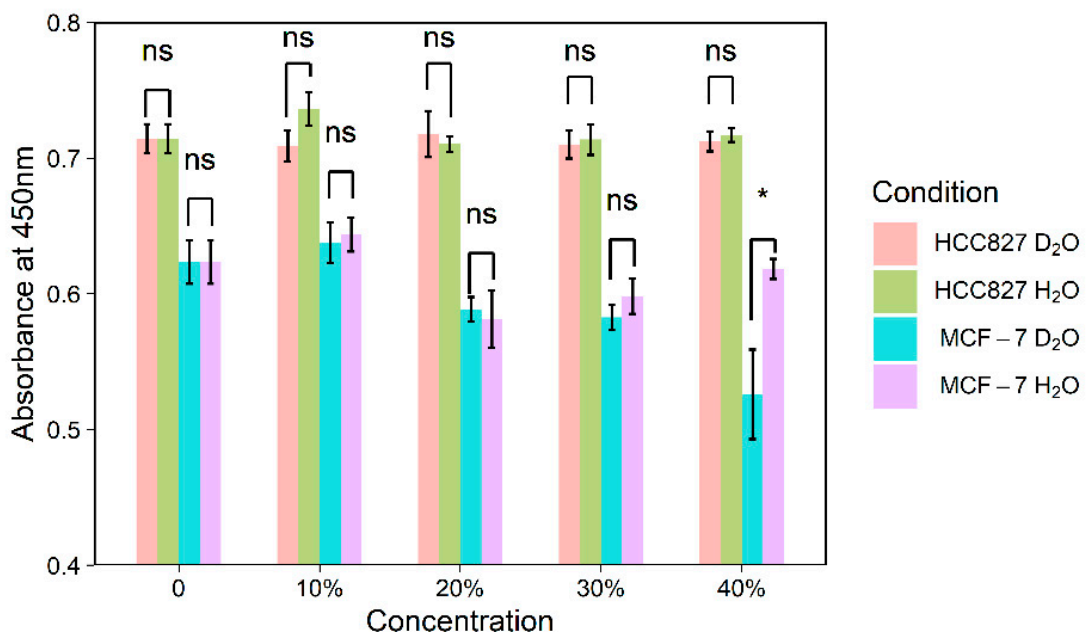

Figure 4. Relative cell viability after $24 \mathrm{~h}$ of incubation in $\mathrm{D}_{2} \mathrm{O}$ and $\mathrm{H}_{2} \mathrm{O}$. Error bars represent the standard deviation of eight replicates. * $p \leq 0.05$; ns: $p>0.05$, no significance.

Figures $\mathrm{S} 4$ and $\mathrm{S} 5$ show that the morphologies of MCF-7 were maintained after being cultured in $\mathrm{D}_{2} \mathrm{O}$-containing medium. With respect to HCC 827 cells, it is noted that $\mathrm{D}_{2} \mathrm{O}$ concentrations of up to $40 \%$ did not interfere with cell viability. In contrast, the same concentration resulted in a significant decline in cell viability of MCF-7 cells. This result justified our selection of $30 \% \mathrm{D}_{2} \mathrm{O}$ as the optimal labeling concentration. These results of the present study are consistent with previous studies which suggested that higher intracellular $\mathrm{D}_{2} \mathrm{O}$ concentration may have a negative effect on cell viability [28,29]. The different growth rate of HCC 827 and MCF-7 might attribute to the occurring of differences in cytotoxicity under $40 \% \mathrm{D}_{2} \mathrm{O}$. MCF-7 cells grow faster than HCC 827 with the doubling time is $24 \mathrm{~h}$ versus $71 \mathrm{~h}[25,26]$. The faster growing MCF-7 cells takes in more deuterium than HCC 827 cells during a same incubating time, which inhibits the cell growth and reduce cell viability.

\subsection{Chemotherapy Drug Efficacy Sensing by Single-Cell Raman-DIP}

To evaluate the reliability of our single-cell Raman-DIP approach for anticancer drug efficacy screening, we studied the metabolic index and cell viability of the two cell lines (HCC827 and MCF-7) exposed to various anticancer drugs via Raman-DIP and classical CTG assay, respectively. The CTG kit allows for sensitive luminescence assays for the determination of cell viability in cytotoxicity assays. It detects the luminescence generated by the luciferase-catalyzed transformation of luciferin that only occurs in viable cells. The luminescent signal is proportional to the number of living cells [27]. The relative cell viability was used to assess $\mathrm{D}_{2} \mathrm{O}$ inhibition and was defined as the percentage of luminescence of $\mathrm{D}_{2} \mathrm{O}$-incubated sample to that of the negative control. The metabolic ratio was used to assess the drug inhibition detected by single-cell Raman-DIP and was 
defined as the percentage of metabolic index of drug-treated sample to that of the negative control sample. Figure 5A,B show the relative cell activity and metabolic ratio of HCC827 and MCF-7, respectively. The dose-effect curve clearly indicated the trend of sigmoidal fitting-the relative cell viability decreased after $72-144 \mathrm{~h}$ of exposure to drugs as the dose of the drug increased.
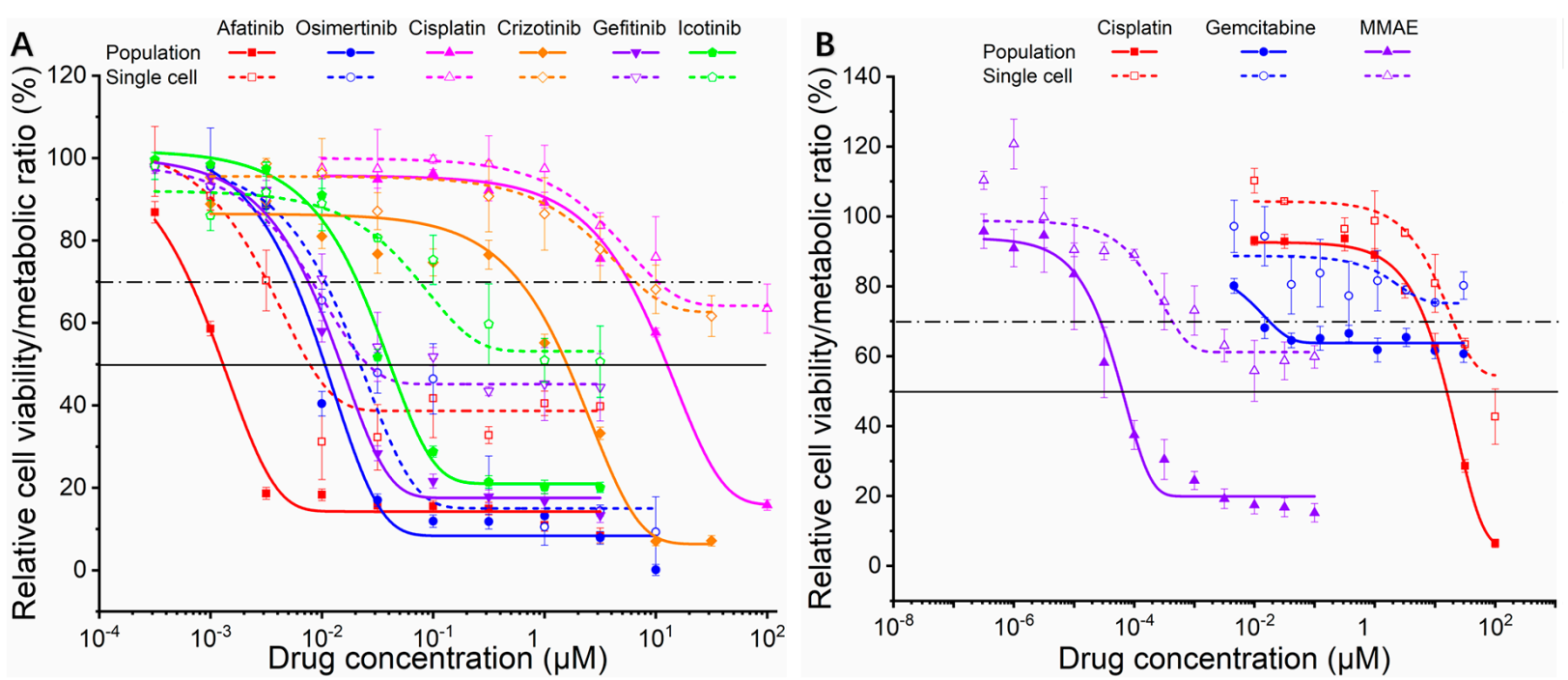

Figure 5. Dose-effect curve of relative cell viability obtained at the bulk level and metabolic ratio obtained at the single-cell level for HCC827 (A) and MCF-7 (B) toward different chemotherapy drugs. Colored solid curves represent the dose-effect curves at the population level. Colored dashed curves represent the dose-effect curves at the single-cell level. The horizontal solid lines and dotted-dashed lines indicate the level of $50 \%$ of relative cell viability and $70 \%$ of metabolic ratio, respectively. Error bars represent the standard deviation among the replicates.

The changes in metabolic ratio by Raman-DIP after $24 \mathrm{~h}$ of drug exposure showed a very similar trend and was also described by sigmoidal fitting. However, the metabolic ratios of single cells were generally higher than the relative cell viabilities of cell populations (as shown by the dash lines appearing above the solid lines in Figure 5). The reason might be that the single cell metabolism indicator was measured regardless of cell numbers while effective anticancer drugs could increase the cell doubling time and lessen the total cell number [30]. Future studies based on Raman-DIP could consider both cell numbers and single cell metabolic activities to establish an even more sensitive model.

The $\mathrm{IC}_{50} \mathrm{~s}$ of chemicals were classical benchmark to evaluate drug's efficacy. $\mathrm{The} \mathrm{IC}_{50} \mathrm{~s}$ from the CTG assay were estimated with sigmoidal fitting and are presented in Table 1 . The data show that HCC827 was resistant to cisplatin, while MCF-7 was resistant to cisplatin and gemcitabine $\left(\mathrm{IC}_{50} \mathrm{~s}>10 \mu \mathrm{M}\right)$. We calculated the $\mathrm{IC}_{20} \mathrm{~s}, \mathrm{IC}_{30} \mathrm{~s}$, and $\mathrm{IC}_{40} \mathrm{~s}$ from the RamanDIP assay (listed in Table 1 and Table S3) and proposed to use $\mathrm{IC}_{30}$ as a criterion in the Raman-DIP approach to evaluate drug efficacy because the $\mathrm{IC}_{30}$ values were all on the same order of magnitude as $\mathrm{IC}_{50}$ from the population-level approach. These metrics give the highest sensitivity, specificity, and accuracy (100\%) among all criteria (Table 1 and Table S4).

The $\mathrm{IC}_{30}$ results indicate that both $\mathrm{HCC} 827$ and MCF-7 were resistant to cisplatin, while MCF-7 was insensitive to gemcitabine. This agreed well with the results from populational analysis and other studies that use the MTT assay [27,31-34]. The CTG kit used here is a derivative of the MTT assay - a gold-standard approach for in vitro drug efficacy identification [35]. In short, our results from a panel of eight drugs on two cancer cell lines demonstrated that single-cell Raman-DIP could track the variation of cellular metabolic activity and could also shorten a lengthy $72-144 \mathrm{~h}$ in vitro drug sensitivity test procedure to $48 \mathrm{~h}$. Hence, this reduction in time potentially lowers the cost for drug 
screening and speeds up the process for determining the correct cancer treatment for individuals.

Table 1. The $\mathrm{IC}_{50}$ and $\mathrm{IC}_{30}(\mu \mathrm{M})$ of different chemotherapy drugs and their drug resistance.

\begin{tabular}{|c|c|c|c|c|c|}
\hline \multirow[b]{2}{*}{ Cell Lines } & \multirow[b]{2}{*}{ Drugs } & \multicolumn{2}{|c|}{ Population Level Analysis } & \multicolumn{2}{|c|}{ Single-Cell Raman-DIP } \\
\hline & & $\mathrm{IC}_{50}(\mu \mathrm{M})$ & $\begin{array}{c}\text { Drug } \\
\text { Resistance }\end{array}$ & $\mathrm{IC}_{30}(\mu \mathrm{M})$ & $\begin{array}{c}\text { Drug } \\
\text { Resistance }\end{array}$ \\
\hline \multirow{6}{*}{ HCC 827} & Afatinib & 0.0013 & $S$ & 0.0032 & $S$ \\
\hline & Cisplatin & 12.56 & $\mathrm{R}$ & 10.35 & $\mathrm{R}$ \\
\hline & Crizotinib & 1.59 & $\mathrm{~S}$ & 6.54 & $\mathrm{~S}$ \\
\hline & Gefitinib & 0.015 & $S$ & 0.0082 & $S$ \\
\hline & Icotinib & 0.041 & $\mathrm{~S}$ & 0.076 & $\mathrm{~S}$ \\
\hline & Osimertinib & 0.011 & $S$ & 0.010 & $S$ \\
\hline \multirow{3}{*}{ MCF-7 } & Cisplatin & 15.67 & $\mathrm{R}$ & 20.10 & $\mathrm{R}$ \\
\hline & Gemcitabine & $>30$ & $\mathrm{R}$ & $>30$ & $\mathrm{R}$ \\
\hline & MMAE & $6.33 \times 10^{-5}$ & $\mathrm{~S}$ & $4.29 \times 10^{-4}$ & $\mathrm{~S}$ \\
\hline \multicolumn{4}{|c|}{ Sensitivity of $\mathrm{IC}_{30}$} & \multicolumn{2}{|c|}{1.0} \\
\hline \multicolumn{4}{|c|}{ Specificity of $\mathrm{IC}_{30}$} & \multicolumn{2}{|c|}{1.0} \\
\hline \multicolumn{4}{|c|}{ Accuracy of $\mathrm{IC}_{30}$} & \multicolumn{2}{|c|}{1.0} \\
\hline
\end{tabular}

MMAE: Monomethyl auristatin E; R: Resistant, S: Sensitive.

\subsection{The Heterogenous Response of Cells to Chemotherapy Drugs}

Cancers are composed of mixed cell populations with diverse characteristics. Intratumor heterogeneity describes the tumor heterogeneity observed among tumor cells within one host organ [36,37] and is often associated with the heterogeneous resistance of cancer cells to anticancer drugs and treatment failure [38]. Though in vitro drug sensitivity tests, such as MTT and CTG assays on acquired tumor cells from patients could predict the outcome of the treatment and guide the medication, they are unreliable because these assays cannot elucidate the heterogeneous resistance occurred at the single-cell level. In contrast, the variation in cell heterogeneity can be detected by single-cell Raman-DIP sensing that measures metabolic activity at the single-cell level.

Figure 6 exhibits a metabolic ratio of 150 single HCC827 cells exposed to crizotinib at various concentrations. Although the general pattern of descending metabolic ratio was observed with increasing drug dose, the distribution of metabolic ratio among cells from the same treatment clearly shows a subpopulation consisting of only a few $(\sim 1 \%)$ single cells with an undisturbed metabolic activity. Strong C-D bands were present in the SCRS of cells in this subpopulation. This was probably due to drug resistance. Lung cancer is highly heterogeneous with respect to metabolic activity at the single-cell level $[39,40]$. Our results implied the possibility of applying Raman-DIP to patient tumor cells, and in vitro assessments of the heterogeneous phenotypic drug susceptibility can thus be performed. This is a promising complement to single-cell RNA sequencing, which remains an expensive but powerful tool for genotypic heterogeneity. Both approaches can shed light on the variations in tumor heterogeneity $[40,41]$. 


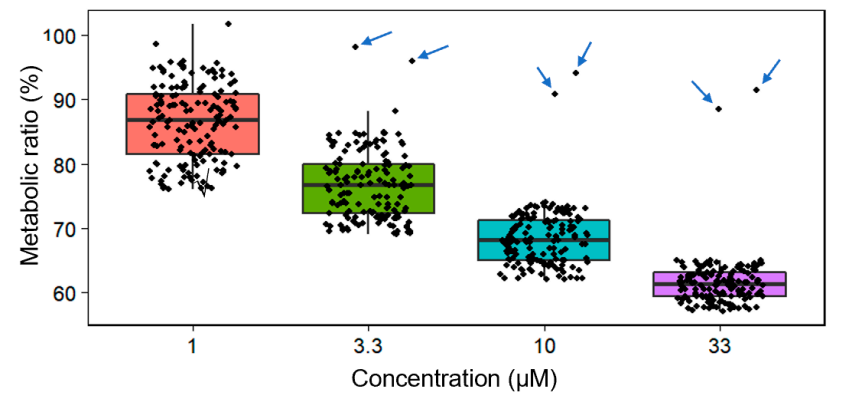

Figure 6. The metabolic ratio distribution of single HCC827 cells treated with crizotinib at different concentrations. Single cells $(n=150)$ were analyzed in each treatment. Some cells exhibited extreme metabolic ratios that were numerically distant from the rest of the data; these are marked with arrows.

\section{Conclusions}

In this study, we developed an accurate, sensitive, and rapid in vitro anticancer drug effect sensing method, i.e., Raman-DIP. The method is based on single-cell Raman microscopy coupled with deuterium labeling. Raman-DIP sensing measures the cell metabolic activity, as indicated by the C-D band in SCRS. We applied Raman-DIP to two tumor cell lines and assessed their susceptibility to eight anticancer drugs. The results showed that Raman-DIP could detect cancer cell metabolic activity at the single-cell level. The optimal labeling condition was $24 \mathrm{~h}$ of incubation in 30\% deuterated medium. The inhibition of HCC 827 and MCF-7 metabolic activity by anticancer drugs was sensitively detected via Raman-DIP. The results are consistent with the cell viability result measured by a classical MTT assay at the population level.

The features of the single-cell Raman-DIP-based method with other in vitro techniques are compared in Table 2. Raman-DIP shortened the duration of in vitro drug tests from $72-144 \mathrm{~h}$ to $48 \mathrm{~h}$. Here, $12 \mathrm{~h}$ of labeling in $\mathrm{D}_{2} \mathrm{O}$ was sufficient for the detection of cancer cell metabolic activity at single cell level, and the assay duration could thus potentially be further reduced. Moreover, this approach solves issues with false positive results caused by toxic compounds used in other in vitro assays; hence, there was increased accuracy of drug screening. The single-cell resolution provided by Raman-DIP for identifying heterogeneous resistance was another benefit over population level assay. In conclusion, this proof-ofconcept study demonstrated the potential of Raman-DIP as a reliable and novel tool to lower the attrition rate of cancer drug development and to increase patient welfare.

Table 2. Comparison of some in vitro anticancer drug efficacy screening techniques.

\begin{tabular}{|c|c|c|c|c|}
\hline & MTT Assays & 3D Cell Culture & Raman SERS & $\begin{array}{c}\text { Single-Cell Raman } \\
\text { DIP }\end{array}$ \\
\hline $\begin{array}{c}\text { Toxic reagent } \\
\text { (False-positive results) }\end{array}$ & Yes & No & No & No \\
\hline Culture apparatus & Multi-well plate/slide & $\begin{array}{c}\text { Specially designed } \\
\text { device }\end{array}$ & SERS chip & Multi-well plate/slide \\
\hline Sensing device & Plate reader & Confocal microscope & Raman microscope & Raman microscope \\
\hline Duration & 72-144 h & $>72 \mathrm{~h}$ & $24-48 \mathrm{~h}$ & $24-48 \mathrm{~h}$ \\
\hline Cost & Low & High & Low & Low \\
\hline Universality & $\begin{array}{l}\text { Universal biomarker } \\
\text { for most cancer cells } \\
\text { and drugs }\end{array}$ & $\begin{array}{l}\text { Limited types of cancer } \\
\text { cell grow into 3D } \\
\text { structure under lab } \\
\text { condition }\end{array}$ & $\begin{array}{l}\text { Not universal } \\
\text { biomarker }\end{array}$ & $\begin{array}{l}\text { Universal biomarker } \\
\text { for most cancer cells } \\
\text { and drugs }\end{array}$ \\
\hline $\begin{array}{l}\text { Single-cell } \\
\text { heterogeneity sensing }\end{array}$ & No & Yes & Not demonstrated & Yes \\
\hline References & [3-7] & {$[2,3]$} & {$[10,11]$} & This study \\
\hline
\end{tabular}


Supplementary Materials: The following are available online at https: / www.mdpi.com/article/ 10.3390/bios11080286/s1, Figure S1. Detailed system schematic of the home-built confocal Raman spectrometer. Figure S2. Changes in Raman intensities for nucleic acid $\left(781 \mathrm{~cm}^{-1}\right)$, protein $\left(1240 \mathrm{~cm}^{-1}\right)$, protein and lipids $\left(1450 \mathrm{~cm}^{-1}\right)$, and carbon-deuterium bond $\left(2170 \mathrm{~cm}^{-1}\right)$ of HCC 827 and MCF-7 cell lines under different D2O concentrations. Figure S3. Illustration of deuterium from $\mathrm{D}_{2} \mathrm{O}$ incorporation to biomolecules by active cells. Figure S4. Bright-field microscopic images (50× objective) of MCF-7 cells treated with $\mathrm{D}_{2} \mathrm{O}$ for $12 \mathrm{~h}$. Figure S5. Bright-field microscopic images (50× objective) of MCF-7 cells treated with $\mathrm{D}_{2} \mathrm{O}$ for $36 \mathrm{~h}$. Table S1. The specifications of the confocal Raman spectrometer. Table S2. The difference of viability of cancer cells at different $\mathrm{D}_{2} \mathrm{O} / \mathrm{H}_{2} \mathrm{O}$ concentrations. Table $\mathrm{S} 3$. $\mathrm{IC}_{20}, \mathrm{IC}_{30}$, and $\mathrm{IC}_{40}$ of different chemotherapy drugs. Table S4. Sensitivity, specificity, and accuracy of the criterions $\mathrm{IC}_{20}, \mathrm{IC}_{30}$, and $\mathrm{IC}_{40}$.

Author Contributions: Literature retrieval, system design, data collection, and manuscript writing: J.W.; data analysis and figure construction: K.L.; system building: H.H.; writing, review, and editing: X.Q.; data analysis and editing: W.E.H.; methodology, writing, review, and editing: Z.C.; funding acquisition, methodology, and editing: Y.G.; conceptualization, writing, review, and editing: Y.S. All authors have read and agreed to the published version of the manuscript.

Funding: The study was supported by the National Natural Science Foundation of China (61975228 and 42076165), the Instrument Developing Project of Chinese Academy of Sciences (YJKYYQ20200038 and ZDKYYQ20200004), and SIBET funding (E0290104).

Institutional Review Board Statement: Not applicable.

Informed Consent Statement: Not applicable.

Data Availability Statement: Not applicable.

Acknowledgments: We appreciate the technical support from Innomodels for cell viability testing. We thank LetPub for its linguistic assistance during the preparation of this manuscript.

Conflicts of Interest: The authors declare no conflict of interest.

\section{References}

1. Hay, M.; Thomas, D.W.; Craighead, J.L.; Economides, C.; Rosenthal, J. Clinical development success rates for investigational drugs. Nat. Biotechnol. 2014, 32, 40-51. [CrossRef]

2. Kitaeva, K.V.; Rutland, C.S.; Rizvanov, A.A.; Solovyeva, V.V. Cell Culture Based in vitro Test Systems for Anticancer Drug Screening. Front. Bioeng. Biotechnol. 2020, 8, 322. [CrossRef] [PubMed]

3. Popova, A.A.; Levkin, P.A. Precision Medicine in Oncology: In Vitro Drug Sensitivity and Resistance Test (DSRT) for Selection of Personalized Anticancer Therapy. Adv. Ther. 2020, 3, 1900100. [CrossRef]

4. Hatzis, C.; Bedard, P.L.; Birkbak, N.J.; Beck, A.H.; Aerts, H.J.W.L.; Stern, D.F.; Shi, L.; Clarke, R.; Quackenbush, J.; Haibe-Kains, B. Enhancing Reproducibility in Cancer Drug Screening: How Do We Move Forward? Cancer Res. 2014, 74, 4016-4023. [CrossRef] [PubMed]

5. Lu, D.-Y.; Lu, T.-R.; Ding, J.; Xu, B.; Che, J.-Y.; Wu, H.-Y. Anticancer Drug Sensitivity Testing, a Historical Review and Future Perspectives. Curr. Drug Ther. 2015, 10, 44-55. [CrossRef]

6. Wang, S.; Yu, H.; Wickliffe, J.K. Limitation of the MTT and XTT assays for measuring cell viability due to superoxide formation induced by nano-scale $\mathrm{TiO}_{2}$. Toxicol. In Vitro 2011, 25, 2147-2151. [CrossRef]

7. Larsson, P.; Engqvist, H.; Biermann, J.; Werner Rönnerman, E.; Forssell-Aronsson, E.; Kovács, A.; Karlsson, P.; Helou, K.; Parris, T.Z. Optimization of cell viability assays to improve replicability and reproducibility of cancer drug sensitivity screens. Sci. Rep. 2020, 10, 5798. [CrossRef]

8. Zhang, Y.; Xu, J.; Yu, Y.; Shang, W.; Ye, A. Anti-Cancer Drug Sensitivity Assay with Quantitative Heterogeneity Testing Using Single-Cell Raman Spectroscopy. Molecules 2018, 23, 2903. [CrossRef]

9. Petersen, M.; Yu, Z.; Lu, X. Application of Raman Spectroscopic Methods in Food Safety: A Review. Biosensors 2021, 11, 187. [CrossRef] [PubMed]

10. El-Said, W.A.; Yoon, J.; Choi, J.W. Nanostructured surfaces for analysis of anticancer drug and cell diagnosis based on electrochemical and SERS tools. Nano Converg. 2018, 5, 11. [CrossRef]

11. Ilkhani, H.; Hughes, T.; Li, J.; Zhong, C.J.; Hepel, M. Nanostructured SERS-electrochemical biosensors for testing of anticancer drug interactions with DNA. Biosens. Bioelectron. 2016, 80, 257-264. [CrossRef] [PubMed]

12. Huang, W.E.; Ferguson, A.; Singer, A.C.; Lawson, K.; Thompson, I.P.; Kalin, R.M.; Larkin, M.J.; Bailey, M.J.; Whiteley, A.S. Resolving Genetic Functions within Microbial Populations: In Situ Analyses Using rRNA and mRNA Stable Isotope Probing Coupled with Single-Cell Raman-Fluorescence In Situ Hybridization. Appl. Environ. Microbiol. 2009, 75, 234-241. [CrossRef] [PubMed] 
13. Wang, Y.; Song, Y.; Tao, Y.; Muhamadali, H.; Goodacre, R.; Zhou, N.Y.; Preston, G.M.; Xu, J.; Huang, W.E. Reverse and Multiple Stable Isotope Probing to Study Bacterial Metabolism and Interactions at the Single Cell Level. Anal. Chem. 2016, 88, 9443-9450. [CrossRef] [PubMed]

14. Song, Y.; Cui, L.; López, J.Á.S.; Xu, J.; Zhu, Y.-G.; Thompson, I.P.; Huang, W.E. Raman-Deuterium Isotope Probing for in-situ identification of antimicrobial resistant bacteria in Thames River. Sci. Rep. 2017, 7, 16648. [CrossRef] [PubMed]

15. Yi, X.; Song, Y.; Xu, X.; Peng, D.; Wang, J.; Qie, X.; Lin, K.; Yu, M.; Ge, M.; Wang, Y.; et al. Development of a Fast Raman-Assisted Antibiotic Susceptibility Test (FRAST) for the Antibiotic Resistance Analysis of Clinical Urine and Blood Samples. Anal. Chem. 2021, 93, 5098-5106. [CrossRef] [PubMed]

16. Berry, D.; Mader, E.; Lee, T.K.; Woebken, D.; Wang, Y.; Zhu, D.; Palatinszky, M.; Schintimeister, A.; Schmid, M.C.; Hanson, B.T.; et al. Tracking heavy water $\left(\mathrm{D}_{2} \mathrm{O}\right)$ incorporation for identifying and sorting active microbial cells. Proc. Natl. Acad. Sci. USA 2015, 112, E194-E203. [CrossRef]

17. Tao, Y.; Wang, Y.; Huang, S.; Zhu, P.; Huang, W.E.; Ling, J.; Xu, J. Metabolic-Activity-Based Assessment of Antimicrobial Effects by D2O-Labeled Single-Cell Raman Microspectroscopy. Anal. Chem. 2017, 89, 4108-4115. [CrossRef]

18. Yang, K.; Li, H.Z.; Zhu, X.; Su, J.Q.; Ren, B.; Zhu, Y.G.; Cui, L. Rapid Antibiotic Susceptibility Testing of Pathogenic Bacteria Using Heavy-Water-Labeled Single-Cell Raman Spectroscopy in Clinical Samples. Anal. Chem. 2019, 91, 6296-6303. [CrossRef]

19. Hong, W.; Karanja, C.W.; Abutaleb, N.S.; Younis, W.; Zhang, X.; Seleem, M.N.; Cheng, J.-X. Antibiotic Susceptibility Determination within One Cell Cycle at Single-Bacterium Level by Stimulated Raman Metabolic Imaging. Anal. Chem. 2018, 90, 3737-3743. [CrossRef]

20. Zhang, M.; Hong, W.; Abutaleb, N.S.; Li, J.; Dong, P.-T.; Zong, C.; Wang, P.; Seleem, M.N.; Cheng, J.-X. Rapid Determination of Antimicrobial Susceptibility by Stimulated Raman Scattering Imaging of $\mathrm{D}_{2} \mathrm{O}$ Metabolic Incorporation in a Single Bacterium. Adv. Sci. 2020, 7, 2001452. [CrossRef]

21. Huang, W.E.; Griffiths, R.I.; Thompson, I.P.; Bailey, M.J.; Whiteley, A.S. Raman Microscopic Analysis of Single Microbial Cells. Anal. Chem. 2004, 76, 4452-4458. [CrossRef]

22. Zhang, B.; Xu, H.; Chen, J.; Zhu, X.; Xue, Y.; Yang, Y.; Ao, J.; Hua, Y.; Ji, M. Highly specific and label-free histological identification of microcrystals in fresh human gout tissues with stimulated Raman scattering. Theranostics 2021, 11, 3074-3088. [CrossRef]

23. Song, Y.; Yin, H.; Huang, W.E. Raman activated cell sorting. Curr. Opin. Chem. Biol. 2016, 33, 1-8. [CrossRef]

24. Xu, J.; Zhu, D.; Ibrahim, A.D.; Allen, C.C.R.; Gibson, C.M.; Fowler, P.W.; Song, Y.; Huang, W.E. Raman Deuterium Isotope Probing Reveals Microbial Metabolism at the Single-Cell Level. Anal. Chem. 2017, 89, 13305-13312. [CrossRef]

25. Sutherland, R.L.; Hall, R.E.; Taylor, I.W. Cell proliferation kinetics of MCF-7 human mammary carcinoma cells in culture and effects of tamoxifen on exponentially growing and plateau-phase cells. Cancer Res. 1983, 43, 3998-4006. [PubMed]

26. Cowley, G.S.; Weir, B.A.; Vazquez, F.; Tamayo, P.; Scott, J.A.; Rusin, S.; East-Seletsky, A.; Ali, L.D.; Gerath, W.F.; Pantel, S.E.; et al. Parallel genome-scale loss of function screens in 216 cancer cell lines for the identification of context-specific genetic dependencies. Sci. Data 2014, 1, 140035. [CrossRef] [PubMed]

27. Cai, L.; Qin, X.; Xu, Z.; Song, Y.; Jiang, H.; Wu, Y.; Ruan, H.; Chen, J. Comparison of Cytotoxicity Evaluation of Anticancer Drugs between Real-Time Cell Analysis and CCK-8 Method. ACS Omega 2019, 4, 12036-12042. [CrossRef]

28. Hekmatara, M.; Heidari Baladehi, M.; Ji, Y.; Xu, J. D2 O-Probed Raman Microspectroscopy Distinguishes the Metabolic Dynamics of Macromolecules in Organellar Anticancer Drug Response. Anal. Chem. 2021, 93, 2125-2134. [CrossRef]

29. Kalkur, R.S.; Ballast, A.C.; Triplett, A.R.; Spendier, K. Effects of deuterium oxide on cell growth and vesicle speed in RBL-2H3 cells. PeerJ 2014, 2, e553. [CrossRef] [PubMed]

30. Falgreen, S.; Laursen, M.B.; Bødker, J.S.; Kjeldsen, M.K.; Schmitz, A.; Nyegaard, M.; Johnsen, H.E.; Dybkær, K.; Bøgsted, M. Exposure time independent summary statistics for assessment of drug dependent cell line growth inhibition. BMC Bioinform. 2014, 15, 168. [CrossRef] [PubMed]

31. Dullin, A.; Dufrasne, F.; Gelbcke, M.; Gust, R. Synthesis and Cytotoxicity of Enantiomerically Pure [1,2-Diamino-1-(4fluorophenyl)-3-methylbutane]platinum(II) Complexes. ChemMedChem 2006, 1, 644-653. [CrossRef]

32. Tsai, C.-M.; Chen, J.-T.; Stewart, D.J.; Chiu, C.-H.; Lai, C.-L.; Hsiao, S.-Y.; Chen, Y.-M.; Chang, K.-T. Antagonism between Gefitinib and Cisplatin in Non-Small Cell Lung Cancer Cells: Why Randomized Trials Failed? J. Thorac. Oncol. 2011, 6, 559-568. [CrossRef]

33. Suberu, J.; Romero-Canelón, I.; Sulluvan, N.; Lapkin, A.; Barker, G. Comparative Cytotoxicity of Artemisinin and Cisplatin and Their Interactions with Chlorogenic Acids in MCF7 Breast Cancer Cells. ChemMedChem 2014, 9, 2791-2797. [CrossRef] [PubMed]

34. Tang, Z.-H.; Su, M.-X.; Guo, X.; Xiao-Ming, J.; Jia, L.; Chen, X.; Lu, J.-J. Increased Expression of IRE1 $\alpha$ Associates with the Resistant Mechanism of Osimertinib (AZD9291)-resistant non-small Cell Lung Cancer HCC827/OSIR Cells. Anti-Cancer Agents Med. Chem. 2018, 18, 550-555. [CrossRef]

35. Ling, T.; Lang, W.H.; Maier, J.; Quintana Centurion, M.; Rivas, F. Cytostatic and Cytotoxic Natural Products against Cancer Cell Models. Molecules 2019, 24, 2012. [CrossRef]

36. Vitale, I.; Shema, E.; Loi, S.; Galluzzi, L. Intratumoral heterogeneity in cancer progression and response to immunotherapy. Nat. Med. 2021, 27, 212-224. [CrossRef] [PubMed]

37. Gerashchenko, T.S.; Denisov, E.V.; Litviakov, N.V.; Zavyalova, M.V.; Vtorushin, S.V.; Tsyganov, M.M.; Perelmuter, V.M.; Cherdyntseva, N.V. Intratumor heterogeneity: Nature and biological significance. Biochemistry 2013, 78, 1201-1215. [CrossRef]

38. Sosa Iglesias, V.; Giuranno, L.; Dubois, L.J.; Theys, J.; Vooijs, M. Drug Resistance in Non-Small Cell Lung Cancer: A Potential for NOTCH Targeting? Front. Oncol. 2018, 8, 267. [CrossRef] [PubMed] 
39. Hensley, C.T.; Faubert, B.; Yuan, Q.; Lev-Cohain, N.; Jin, E.; Kim, J.; Jiang, L.; Ko, B.; Skelton, R.; Loudat, L. Metabolic heterogeneity in human lung tumors. Cell 2016, 164, 681-694. [CrossRef]

40. Qian, J.; Olbrecht, S.; Boeckx, B.; Vos, H.; Laoui, D.; Etlioglu, E.; Wauters, E.; Pomella, V.; Verbandt, S.; Busschaert, P.; et al. A pan-cancer blueprint of the heterogeneous tumor microenvironment revealed by single-cell profiling. Cell Res. 2020, 30, 745-762. [CrossRef]

41. Shin, D.; Lee, W.; Lee, J.H.; Bang, D. Multiplexed single-cell RNA-seq via transient barcoding for simultaneous expression profiling of various drug perturbations. Sci. Adv. 2019, 5, eaav2249. [CrossRef] [PubMed] 